\title{
Late winter under ice pelagic microbial communities in the high Arctic Ocean and the impact of short-term exposure to elevated $\mathrm{CO}_{2}$ levels
}

\author{
Adam Monier ${ }^{1,2+\neq}$, Helen S. Findlay ${ }^{3 \neq}$, Sophie Charvet $^{1 \dagger}$ and Connie Lovejoy ${ }^{1,2 *}$ \\ ${ }^{1}$ Département de Biologie, Québec Océan and Institut de Biologie Intégrative et des Systèmes, Université Laval, Québec, QC, Canada \\ 2 Takuvik Joint International Laboratory (CNRS UMI-3376), Université Laval, Québec, QC, Canada \\ ${ }^{3}$ Plymouth Marine Laboratory, Plymouth, UK
}

\section{Edited by:}

Michael Rappe, University of Hawail

at Manoa, USA

\section{Reviewed by:}

Om V. Singh, University of

Pitsburgh, USA

Ida Helene Steen, University of

Bergen, Norway

\section{*Correspondence:}

Connie Lovejoy, Département de Biologie, Université Laval, Pavillon Alexandre Vachon, 1045 Avenue de la Médecine, Québec, QC

G1V OA6, Canada

e-mail: connie.lovejoy@bio.ulaval.ca

${ }^{\dagger}$ Present address:

Adam Monier, Biosciences, College of Life and Environmental Sciences, University of Exeter, Exeter, UK; Sophie Charvet, IOW Leibniz-Institut for Baltic Research Warnemünde, Germany

${ }^{\ddagger}$ These authors have contributed equally to this work.
Polar Oceans are natural $\mathrm{CO}_{2}$ sinks because of the enhanced solubility of $\mathrm{CO}_{2}$ in cold water. The Arctic Ocean is at additional risk of accelerated ocean acidification (OA) because of freshwater inputs from sea ice and rivers, which influence the carbonate system. Winter conditions in the Arctic are of interest because of both cold temperatures and limited $\mathrm{CO}_{2}$ venting to the atmosphere when sea ice is present. Earlier OA experiments on Arctic microbial communities conducted in the absence of ice cover, hinted at shifts in taxa dominance and diversity under lowered $\mathrm{pH}$. The Catlin Arctic Survey provided an opportunity to conduct in situ, under-ice, OA experiments during late Arctic winter. Seawater was collected from under the sea ice off Ellef Ringnes Island, and communities were exposed to three $\mathrm{CO}_{2}$ levels for 6 days. Phylogenetic diversity was greater in the attached fraction compared to the free-living fraction in situ, in the controls and in the treatments. The dominant taxa in all cases were Gammaproteobacteria but acidification had little effect compared to the effects of containment. Phylogenetic net relatedness indices suggested that acidification may have decreased the diversity within some bacterial orders, but overall there was no clear trend. Within the experimental communities, alkalinity best explained the variance among samples and replicates, suggesting subtle changes in the carbonate system need to be considered in such experiments. We conclude that under ice communities have the capacity to respond either by selection or phenotypic plasticity to heightened $\mathrm{CO}_{2}$ levels over the short term.

Keywords: ocean acidification, Arctic Ocean, community structure, phylogenetic diversity, NRI, bottle effect

\section{INTRODUCTION}

Since the industrial revolution, it has been estimated that the world's oceans have absorbed $\sim 25 \%$ of all carbon dioxide $\left(\mathrm{CO}_{2}\right)$ emitted into the atmosphere (Sabine et al., 2004; Sarmiento et al., 2010). This continual and rapid uptake of $\mathrm{CO}_{2}$ into the oceans is resulting in a shift in the ocean carbonate chemistry and a reduction in ocean $\mathrm{pH}$, a process that has been termed ocean acidification (Caldeira and Wickett, 2003; Raven et al., 2005; Doney et al., 2009). The Polar Oceans naturally are sinks to $\mathrm{CO}_{2}$ because $\mathrm{CO}_{2}$ is more soluble in cold water. The Arctic Ocean is believed to be more at risk to accelerated ocean acidification because of the freshwater influence from sea ice and through river inputs (Steinacher et al., 2009). There is already evidence of low $\mathrm{pH}$ and undersaturated conditions in some areas of the Arctic Ocean (Bates et al., 2009; Mathis et al., 2012), and during winter, microbial respiration acts to further elevate $\mathrm{CO}_{2}$ in the surface waters under sea ice (Sabine et al., 2004; Sarmiento et al., 2010; Miller et al., 2011).

Microbial processes are responsible for biogeochemical cycling and functioning of marine ecosystems (Caldeira and Wickett,
2003; Raven et al., 2005; Azam and Malfatti, 2007; Doney et al., 2009) and the Arctic Ocean is no exception, with active bacterial production occurring even in the dark of winter (Garneau et al., 2008; Steinacher et al., 2009). Although ice covered regions appear to have lower bacterial production and abundance than ice-free areas, they also have much higher ratios of bacteria to phytoplankton production (Rich et al., 1997; Bates et al., 2009; Mathis et al., 2012), implying high levels of bacterial respiration. There are few reports of microbial community composition and activity during the Arctic winter, although a number of bacterial taxa remain active over the winter (Krembs et al., 2002; Junge et al., 2004; Galand et al., 2008, 2013). However, the majority of studies to date have investigated microbial processes during the spring, summer and early autumn when the Arctic Ocean is more accessible and under ice winter bacterial communities and processes remain understudied. The continued remineralization of carbon by pelagic bacteria throughout the winter under the sea ice is believed to contribute a significant fraction of the $\mathrm{CO}_{2}$ to the water column (Miller et al., 2011). On a seasonal cycle, the addition or removal of $\mathrm{CO}_{2}$ by microbes contributes significantly to 
the mediation of ocean acidification, which can have implications for the timing and rate of acidification. Therefore, understanding how a shift in climate or ocean acidification might impact bacterial abundance, community or activity is important for determining the feedbacks on biogeochemical cycling.

In the majority of recent ocean acidification experiments, bacterial abundance seems to be unaffected by $\mathrm{CO}_{2}$ levels (RochelleNewall et al., 2004; Grossart et al., 2006; Allgaier et al., 2008). The response of bacterial production to elevated $\mathrm{CO}_{2}$ conditions is not uniform; but most studies show an increase in bacterial production when exposed to elevated $\mathrm{CO}_{2}$ (Liu et al., 2010). The effect of acidification on bacterial community composition is variable; with either no change with increasing $\mathrm{CO}_{2}$ (Mühling et al., 2006; Allgaier et al., 2008; Tanaka et al., 2008), a shift to a community representing an "unhealthy" system, for example in coral-associated bacteria (Thurber et al., 2009), or an indirect effect with community changes associated with a phytoplankton bloom (Allgaier et al., 2008).

Studies addressing the effect of $\mathrm{CO}_{2}$ levels in Arctic Seas are particularly rare but a recent mesocosm experiment in an icefree Arctic fjord reported that Gammaproteobacteria were the only taxon that showed significant changes with increasing $\mathrm{CO}_{2}$. In addition, the relative abundance of 15 rare taxa was significantly correlated with increasing $\mathrm{CO}_{2}$ concentration (Roy et al., 2013). The change in relative abundance of these rare taxa hints at potential shifts in taxa dominance or diversity, but overall the results were difficult to interpret, with major differences between the natural communities of the fjord and those in the mesocosm.

Our study aimed to investigate the direct effects of ocean acidification on under-ice Arctic pelagic bacteria, using cultureindependent, high-resolution molecular techniques to not only assess changes in community structure, but also investigate changes in phylogenetic taxa dominance and diversity between both the particle-attached and the free-living communities. Since the natural community was also monitored before and after the experiment, our analysis also provided an opportunity to explore the influence of confinement, the so-called "bottle effect" on microbial communities.

\section{MATERIALS AND METHODS FIELD AND EXPERIMENTAL PROCEDURES Ice base}

From 15th March to 30th April 2010, the Catlin Ice Base (CIB) was situated at $\mathrm{N} 78^{\circ} 43.11^{\prime}$, W $104^{\circ} 47.44^{\prime}$ on a region of flat, first year sea ice, which extended east to west from Ellef Ringnes Island seaward (Supplementary Figure 1). The sea ice in the area was between 1.5 and $1.7 \mathrm{~m}$ thick. The water depth under the ice was not precisely known, although the maximum depth of the wire on the winch used for obtaining water samples was roughly $230 \mathrm{~m}$, and this did not reach the bottom. The Canadian Hydrographic Service Chart \#7953 (last updated 17/03/1972) suggests that the area is between soundings of 290 and $420 \mathrm{~m}$.

\section{Seawater collection, experimental set up and sampling}

Seawater was collected, using a $10 \mathrm{~L}$ Niskin water bottle through a $1.3 \times 1.1 \mathrm{~m}$ hole in the sea ice, from $25 \mathrm{~m}$ depth and placed initially into three sterilized $25 \mathrm{~L}$ water containers on the 19th April 2010. In each container the carbonate chemistry was manipulated using $\mathrm{HCl}$ and $\mathrm{NaHCO}_{3}$ based on measurements of $\mathrm{pH}$ and alkalinity (Table 1) and calculated using the Seacarb program (Lavigne and Gattuso, 2010) as detailed in the EPOCA Guide to Best Practices (Riebesell et al., 2010). The carbonate system was manipulated so that there were three atmospheric $\mathrm{CO}_{2}$ concentration scenarios: "ambient- $\mathrm{CO}_{2}$ " ( $\left.\sim 400 \mathrm{ppm}\right)$, "mid- $\mathrm{CO}_{2}$ " $(\sim 880 \mathrm{ppm})$, and "high- $\mathrm{CO}_{2}$ " $(\sim 1800 \mathrm{ppm})$. After the manipulations were made, seawater was decanted into three replicate $2 \mathrm{~L}$ incubation bottles (Thermo Scientific Nalgene polycarbonate narrow-mouth bottle) for each treatment. The incubation bottles were maintained at ambient seawater conditions by suspending them on a line through a hole in the sea ice (the hole was $\sim 1 \mathrm{~m}^{2}$ ). The bottles were held $1.5 \mathrm{~m}$ under the ice for the duration of the experiment ( 6 days). The hole was maintained accessible (i.e., minimizing ice growth) by covering with wooden boards at nighttime and removing ice during the day. Because of limited sample processing capacity, the three comparative in situ communities were from separate $10 \mathrm{~m}$ deep seawater samples; two samples were collected prior to OA experiments on 18/04/2010 and 22/04/2010 and one just after the experiment on $04 / 26 / 2010$ (Table 1 ) for both free-living and attached fractions.

Temperature, salinity and $\mathrm{pH}$ were measured at the beginning and the end of the experiment in water samples taken from each

Table 1 | Environmental conditions from the water column under the sea ice over the same period as the ocean acidification experiment (before, during and after): salinity, temperature, dissolved inorganic carbon (DIC), and alkalinity were measured alongside chlorophyll, ammonium, phosphate, nitrate and silicate.

\begin{tabular}{lccc}
\hline & $\mathbf{1 8 / 0 4 / 1 0}$ & $\mathbf{2 2 / 0 4 / 1 0}$ & $\mathbf{2 6 / 0 4 / 1 0}$ \\
\hline Salinity & $30.31( \pm 0.22)$ & $30.36( \pm 0.26)$ & $30.33( \pm 0.12)$ \\
Temp $\left({ }^{\circ} \mathrm{C}\right)$ & $-1.652( \pm 0.002)$ & $-1.650( \pm 0.003)$ & $-1.654( \pm 0.006)$ \\
Alkalinity $\left(\mu \mathrm{mol} \mathrm{kg}^{-1}\right)$ & $2140.5( \pm 4.8)$ & $2143.3( \pm 6.8)$ & $2141.1( \pm 2.2)$ \\
$\left.\mathrm{DIC}(\mu \mathrm{mol} \mathrm{kg})^{-1}\right)$ & $2023.5( \pm 0.6)$ & $2020.8( \pm 2.1)$ & $2023.9( \pm 1.3)$ \\
$\mathrm{pH}_{\mathrm{T}}$ & $8.137( \pm 0.012)$ & $8.152( \pm 0.026)$ & $8.137( \pm 0.007)$ \\
$\mathrm{HCO}_{3}^{-}\left(\mu \mathrm{mol} \mathrm{kg}{ }^{-1}\right)$ & $1914.8( \pm 1.5)$ & $1909.7( \pm 5.7)$ & $1915.1( \pm 2.4)$ \\
$\mathrm{CO}_{3}^{2-}(\mu \mathrm{mol} \mathrm{kg})$ & $88.7( \pm 2.5)$ & $91.9( \pm 5.0)$ & $88.9( \pm 1.6)$ \\
$\left.\mathrm{CO}_{2}(\mu \mathrm{mol} \mathrm{kg})^{-1}\right)$ & $20.0( \pm 1.5)$ & $19.2( \pm 4.3)$ & $19.9( \pm 1.8)$ \\
$p \mathrm{CO}_{2}(\mu \mathrm{atm})$ & $290.4( \pm 8.2)$ & $279.6( \pm 16.9)$ & $290.1( \pm 5.5)$ \\
$\Omega_{\mathrm{Cal}}$ & $2.18( \pm 0.06)$ & $2.25( \pm 0.13)$ & $2.18( \pm 0.04)$ \\
$\Omega_{\text {Arg }}$ & $1.35( \pm 0.04)$ & $1.40( \pm 0.08)$ & $1.35( \pm 0.03)$ \\
$\left.\mathrm{Chlorophyll}(\mu \mathrm{g} \mathrm{L})^{-1}\right)$ & $0.58( \pm 0.11)$ & $0.69( \pm 0.06)$ & $0.73( \pm 0.14)$ \\
Ammonium $(\mu \mathrm{M})$ & $0.26( \pm 0.24)$ & $0.40( \pm 0.15)$ & $0.22( \pm 0.06)$ \\
Phosphate $(\mu \mathrm{M})$ & $0.77( \pm 0.11)$ & $0.70( \pm 0.12)$ & $0.78( \pm 0.03)$ \\
Nitrate $(\mu \mathrm{M})$ & $1.04( \pm 0.15)$ & $1.15( \pm 0.21)$ & $1.18( \pm 0.28)$ \\
Silicate $(\mu \mathrm{M})$ & $6.70( \pm 1.11)$ & $5.93( \pm 1.12)$ & $6.31( \pm 0.55)$ \\
Daily Surface PAR & 18.66 & 22.86 & 28.81 \\
W m & & &
\end{tabular}

$\left(\mathrm{W} \mathrm{m}^{-2}\right.$ )

$\mathrm{pH}_{T}$, bicarbonate ion $\left(\mathrm{HCO}_{3}^{-}\right)$, carbonate ion $\left(\mathrm{CO}_{3}^{2-}\right)$ and aqueous $\mathrm{CO}_{2}$ concentrations, $\mathrm{pCO}_{2}$ and saturation states of calcite $\left(\Omega_{\text {Cal }}\right)$ and aragonite $\left(\Omega_{\text {Arg }}\right)$ were calculated from the measured parameters using $\mathrm{CO}_{2}$ sys. Values are mean \pm 1 standard deviation of the surface water measurements $(0.5,3,5$, and $10 \mathrm{~m})$. Daily surface PAR values were estimated from the NCEP/NCAR surface level downward solar radiation flux $\left(W \mathrm{~m}^{-2} ; 6 \mathrm{~h}\right.$ measurements); values are daily integrations. 
of the incubation bottles (Table 2). Temperature and salinity were measured using a handheld WTW LF197 multi-meter with a Tetra con 325 electrode, and $\mathrm{pH}$ was measured using a handheld a Metrohm $826 \mathrm{pH}$ meter and pH electrode (6.0228.000), and using Amp- and Tris- buffers, to give $\mathrm{pH}$ on total scale, following Dickson et al. (2007). Alkalinity was measured by collecting water samples in $250 \mathrm{~mL}$ borosilicate glass bottles with ground glass stoppers according to standard procedures detailed in Dickson et al. (2007). Samples were stored unfrozen and returned to Plymouth Marine Laboratory (UK) for analysis using the open-cell potentiometric titration method using an automated titrator (repeatability: $\max . \pm 0.1 \%$ at alkalinity $\sim 2300 \mu \mathrm{mol} \mathrm{kg} \mathrm{kg}^{-1}$ ). Calibration was made using Dickson Certified Reference Materials. For community DNA, 2 L of seawater was collected at the end of the experiment, and was first passed through a $50 \mu \mathrm{m}$ mesh then sequentially filtered onto a $3 \mu \mathrm{m}$ polycarbonate filter (Millipore) and a Sterivex $0.2 \mu \mathrm{m}$ filter (Millipore). Filters were stored in lysis buffer $(50 \mathrm{mM}$ Tris, $40 \mathrm{mM}$ EDTA, 0.75 $\mathrm{M}$ sucrose) and kept in liquid nitrogen until extractions at Université Laval (Canada).

\section{DNA extraction, amplification and sequencing}

Community DNA was extracted using a salt $(\mathrm{NaCl})$ extraction protocol (Aljanabi and Martinez, 1997) as modified in Harding et al. (2011) and stored at $-20^{\circ} \mathrm{C}$ until shipment to Argonne National Laboratory where the DNA samples were amplified with identifier tags along with $16 \mathrm{~S}$ primers covering the V3-V4 region (Prof. J. A. Gilbert, Argonne National Laboratory, USA), then cleaned using the MoBio Ultra Clean htp 96 well clean-up kit. The clean amplicons were then quantified using Invitrogen PicoGreen reagent and a plate reader. Different volumes of the amplicons were pooled together into one tube with a target of $10-35 \mathrm{ng}$ of amplicon DNA. The aim was to have similar quantities from each of the samples. Total DNA was quantified

Table 2 | Environmental conditions for the experimental treatments for the duration of the experiment: salinity, temperature, $\mathrm{pH}$ (total), and alkalinity were measured; dissolved inorganic carbon (DIC), bicarbonate ion $\left(\mathrm{HCO}_{3}^{-}\right)$, carbonate ion $\left(\mathrm{CO}_{3}^{2-}\right)$ and aqueous $\mathrm{CO}_{2}$ concentrations, $p \mathrm{CO}_{2}$ and saturation states of calcite $\left(\Omega_{\mathrm{Cal}}\right)$ and aragonite $\left(\Omega_{\mathrm{Arg}}\right)$ were calculated using $\mathrm{CO}_{2}$ sys.

\begin{tabular}{lccc}
\hline & Control & Mid CO & High CO \\
\hline Salinity & $30.2( \pm 0.2)$ & $30.1( \pm 0.1)$ & $30.2( \pm 0.0)$ \\
Temp $\left({ }^{\circ} \mathrm{C}\right)$ & $-1.65( \pm 0.0)$ & $-1.65( \pm 0.0)$ & $-1.65( \pm 0.0)$ \\
$\mathrm{pH}_{\mathrm{T}}$ & $7.999( \pm 0.006)$ & $7.719( \pm 0.011)$ & $7.388( \pm 0.007)$ \\
Alkalinity $\left(\mu \mathrm{mol} \mathrm{kg}^{-1}\right)$ & $2146.5( \pm 50.0)$ & $2149.5( \pm 12.0)$ & $2068.7( \pm 59.8)$ \\
$\left.\mathrm{DIC}(\mu \mathrm{mol} \mathrm{kg})^{-1}\right)$ & $2072.6( \pm 50.0)$ & $2150.1( \pm 13.3)$ & $2161.1( \pm 62.4)$ \\
$\mathrm{HCO}_{3}^{-}\left(\mu \mathrm{mol} \mathrm{kg}^{-1}\right)$ & $1977.7( \pm 48.0)$ & $2057.6( \pm 12.5)$ & $2025.9( \pm 58.6)$ \\
$\mathrm{CO}_{3}^{2-}\left(\mu \mathrm{mol} \mathrm{kg}{ }^{-1}\right)$ & $66.6( \pm 1.5)$ & $36.2( \pm 0.8)$ & $16.7( \pm 0.6)$ \\
$\mathrm{CO}_{2}\left(\mu \mathrm{mol} \mathrm{kg}{ }^{-1}\right)$ & $28.4( \pm 1.0)$ & $56.3( \pm 1.6)$ & $118.5( \pm 3.7)$ \\
$\mathrm{pCO}_{2}(\mu \mathrm{atm})$ & $412.0( \pm 13.5)$ & $817.6( \pm 22.9)$ & $1722.9( \pm 54.2)$ \\
$\Omega_{\mathrm{Cal}}$ & $1.64( \pm 0.03)$ & $0.89( \pm 0.02)$ & $0.41( \pm 0.02)$ \\
$\Omega_{\mathrm{Arg}}$ & $1.02( \pm 0.02)$ & $0.55( \pm 0.01)$ & $0.26( \pm 0.01)$ \\
\hline
\end{tabular}

Values are mean \pm 1 standard deviation. using a Qubit fluorometer (Life Technologies). Amplicons were sequenced using the Genome Analyser IIx Illumina platform, on which a $12 \times 150$ cycle run, with a 12 bp barcode read followed by a 150 bp sequence read was conducted.

\section{DATA ANALYSES}

\section{Sequence processing}

Illumina reads were first pre-processed through the MG-RAST quality-control pipeline (Meyer et al., 2008). The reads were retrieved from the MG-RAST server and were analyzed using QIIME v1.6 (Caporaso et al., 2010b). Putative chimeric products were detected using UCHIME v4.2 (Edgar et al., 2011) and were removed from subsequent analyses as well as reads shorter than 75 nucleotides. Resulting reads were then clustered into operational taxonomic units (OTUs) with UCLUST, part of the USEARCH v6.0 software suite (Edgar, 2010), using a 97\% sequence identity cutoff. OTUs consisting of only a single read in the entire data set (singletons) were discarded. In addition, one sample triplicate (Mid- $\mathrm{CO}_{2}$, attached fraction, replicate 2) was composed of less than 100 reads passing all filtering steps and was removed from the study. Our dataset was eventually composed of 7,182,447 high quality reads, clustered into 29,753 OTUs distributed across 23 distinct samples (see Supplementary Table 1 for workflow). Catlin OA sequence data are publicly available via MG-RAST (http://metagenomics.anl.gov) under the sample identifiers mgs29275-29294.

\section{Taxonomic classifications}

The OTU representative reads were taxonomically classified using the Ribosomal Database Project (RDP) multi-classifier tool (Wang et al., 2007), with a 50\% assignment confidence cutoff. RDP release 9, with its associated hierarchical taxonomic classification (Cole et al., 2007), was used as the reference sequence database.

\section{Phylogenetic diversity metrics}

To compute phylogenetic beta-diversity measures, we reconstructed an approximate maximum-likelihood phylogenetic tree with FastTree v2.1 (Price et al., 2010) using GTR model and pseudocounts in "accurate mode" (-mlacc 2 -slownni); the phylogenetic tree reconstruction was based on a multiple sequence alignment of all OTU representatives generated with pyNAST (Caporaso et al., 2010a). Weighted (normalized) and unweighted UniFrac distances (Lozupone and Knight, 2005) among the different microbial communities, as well as phylogenetic diversity rarefaction curves were all computed based on the OTU approximate maximum-likelihood phylogenetic tree. Clustering of UniFrac distances was performed using the unweighted pair group method with arithmetic mean (UPGMA) algorithm, and cluster robustness was assessed using 1000 jackknife replicates (on $75 \%$ subsets).

We then investigated the variation in phylogenetic clustering between the different communities by computing net-relatedness index (NRI) (Webb et al., 2002). We reconstructed class-specific phylogenetic trees as above, for each of the sixteen dominant bacterial classes and the plastid 16S rRNA genes that were considered as a single class. The OTUs used for these trees were extracted 
from the multiple sequence alignments. Each phylogenetic tree was then analyzed with the R package "picante" v1.5 (Kembel et al., 2010) to compute abundance weighted mean pairwise distance (MPD) against a null model comprised of 999 randomized trees with taxa shuffling, leading to standardized metrics ( $S E S_{M P D}$, corresponding to $-1 \times \mathrm{NRI}$ ).

\section{Statistical analyses}

Significances in taxonomic diversity differences and phylogenetic metrics among samples were assessed using analyses of variance (ANOVA) and Tukey's HSD post-hoc tests in the R environment (R Development Core Team; www.R-project.org).

For canonical correspondence analyses (CCA), we first conducted a correlation analysis on the environmental variables (Table 1) to avoid redundancy in the multivariate analyses. Correlations were detected between $\mathrm{CO}_{2}$ and $p \mathrm{CO}_{2}$ (of which we kept $p \mathrm{CO}_{2}$ ) and between $\mathrm{CO}_{3}$ and the calcite and aragonite saturation states (of which we kept $\mathrm{CO}_{3}$ ). Subsequently, two CCA were conducted to determine which environmental variables were correlated with changes among the microbial communities for the 12 most abundant phyla and for the Gammaproteobacteria. The OTU abundance data were transformed to relative proportions before conducting the CCA. Both correlation and ordination analyses were performed using PAST software (Hammer et al., 2009).

\section{RESULTS \\ ENVIRONMENTAL PARAMETERS}

To achieve these objectives, we sequenced the $\mathrm{V} 3-\mathrm{V} 4$ regions of the $16 \mathrm{~S}$ small subunit rRNA gene (hereafter 16S) retrieved from natural microbial communities ("in situ") and communities that were subjected to experimental manipulations. The experimental samples were put into $2 \mathrm{~L}$ containers and with three different $\mathrm{CO}_{2}$ concentrations including a bottle control "ambient- $\mathrm{CO}_{2}$ ": (400 ppm), "mid-CO ${ }_{2}$ " (880 ppm), and "high- $\mathrm{CO}_{2}$ " (1800 ppm). Microbial assemblages were retrieved from two size fractions: small or "free-living" $(0.2-3 \mu \mathrm{m})$, and large or "attached" (>3-50 $\mu \mathrm{m})$.

The conditions within the experimental containers were maintained and stable over the 6 days. The salinity, temperature and total alkalinity in the control matched the in situ under-ice surface water conditions, however there were slight differences in other parameters, with lower $\mathrm{pH}$ and higher $\mathrm{DIC}$ and $p \mathrm{CO}_{2}$ conditions in the containers compared to in situ (Tables 1, 2).

\section{PHYLOGENETIC DIVERSITY OF NATURAL AND $\mathrm{CO}_{2}$-TREATED ARCTIC MICROBIAL COMMUNITIES}

Our final $16 \mathrm{~S}$ sequence dataset was composed of more than 7 million quality-controlled reads totaling $\sim 30 \mathrm{k}$ OTUs, across all samples (Supplementary Table 1). Clustering and principal coordinate analyses (PCoA) on both weighted and unweighted UniFrac distances indicated that size fraction (i.e., free-living vs. attached) mainly drove the phylogenetic beta-diversity across microbial assemblages (Figure 1 and Supplementary Figure 2, respectively). Weighted and unweighted distance clustering clearly separated the two size fractions, indicating their distinct phylogenetic compositions (Figure 1A and Supplementary Figure 2A). Moreover, the PCoA showed that phylogenetic compositions of communities from the attached fraction were remarkably more varied compared to those of the free-living

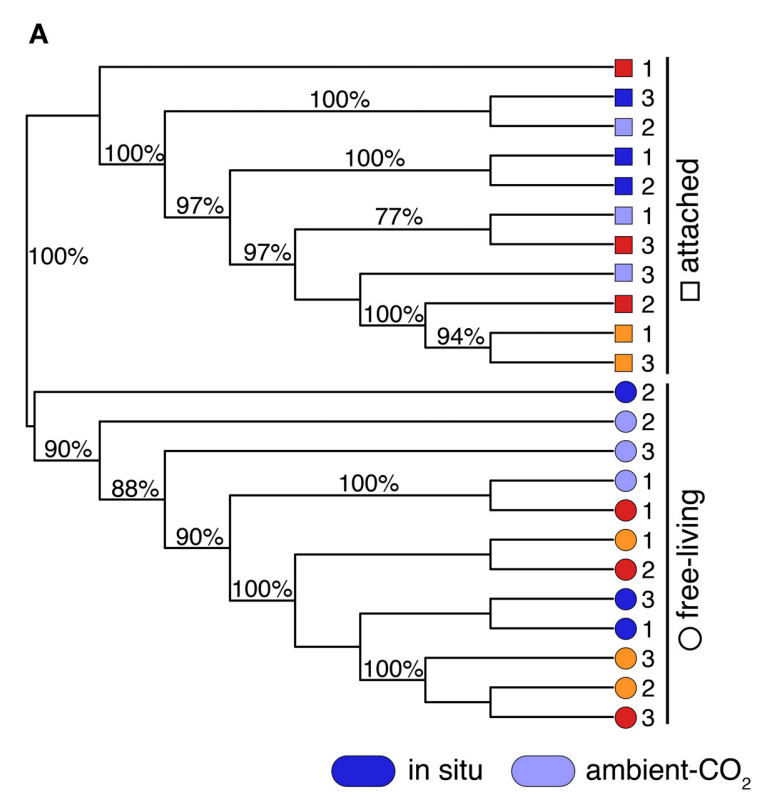

FIGURE 1 | (A) Clustering of 23 Arctic pelagic microbial samples based on UPGMA of weighted and normalized UniFrac distances. Microbial communities were retrieved from two distinct size fractions (free-living: 0.2-3 $\mu \mathrm{m}$; attached: $>3 \mu \mathrm{m}$ ) and were sampled from natural conditions (in situ; dark blue) or from different $\mathrm{CO}_{2}$ concentration treatments:

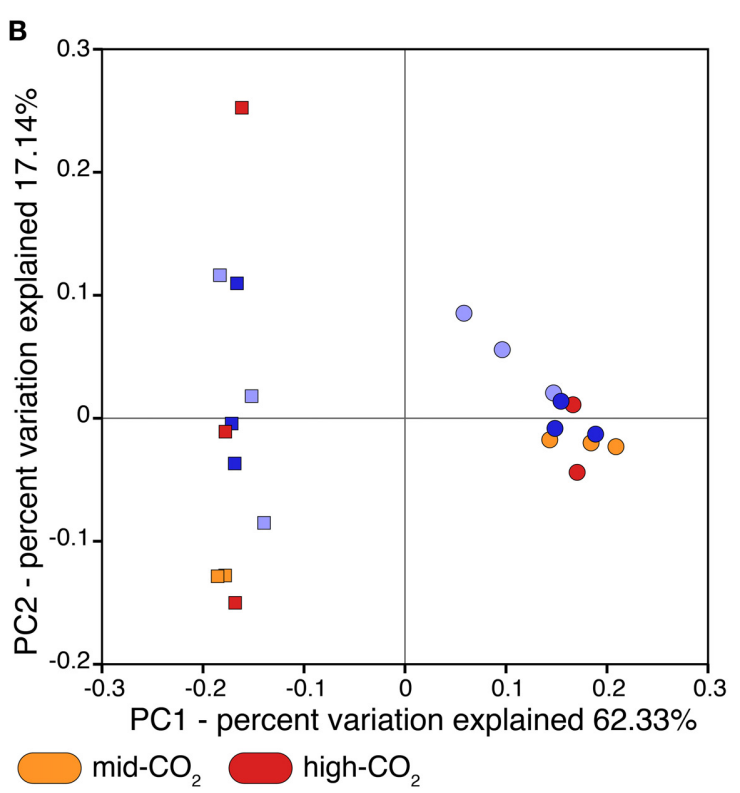

ambient- $\mathrm{CO}_{2}$ (400 ppm; clear blue), mid- $\mathrm{CO}_{2}$ (880 ppm; orange) and high- $\mathrm{CO}_{2}$ (1800 ppm; red). Samples are identified using replicate number. Cluster supports were computed using 1000 jackknife replicates. (B) Corresponding principal coordinate analysis ( $\mathrm{PCOA}$ ) using weighted and normalized UniFrac distances (PC: principal coordinate). 
communities (Figure 1B and Supplementary Figure 2B; along principal coordinate 2). Communities from the free-living fraction were more clustered along principal coordinates, indicating greater phylogenetic similarity among communities than those from the attached fraction.

There was little clustering by treatment with the replicates for the in situ, control, and the mid- and high- $\mathrm{CO}_{2}$ samples interspersed. The free-living fraction of the $\mathrm{CO}_{2}$-treated communities grouped into several supported clusters (Figure 1A), but with no pattern by treatment, and the clustering was not evident when using unweighted UniFrac distances (Supplementary Figure 2A). Two control samples were moderately distant from others when using weighted UniFrac distances (Figure 1B; along principal coordinate 1) but not unweighted ones (Supplementary Figure 2B). For the attached fraction, phylogenetic community composition of one of the high- $\mathrm{CO}_{2}$ replicates was very distant from all other samples, including from other high- $\mathrm{CO}_{2}$ samples, as determined by both weighted and unweighted PCoA analyses (Figure 1B and Supplementary Figure 2B). Also for the particle-attached size fraction, three samples from mid- $\mathrm{CO}_{2}$ and high- $\mathrm{CO}_{2}$ treatments significantly clustered together (Figure 1A and Supplementary Figure 2A).

To test how acidification influenced the diversity of Arctic microbial assemblages, we computed the phylogenetic diversity (PD) of each sample. Using 1000 rarefaction iterations, no significant difference was found in PD among in situ, control and $\mathrm{CO}_{2}$-treated communities, for either size fractions (Figure 2). However, again there was much more variability within the attached fraction, compared to the free-living fraction.

\section{ACIDIFICATION AND DETAILED COMMUNITY TAXONOMIC COMPOSITION}

The taxonomic composition of each microbial community was investigated by comparing relative abundances of $16 \mathrm{~S}$ sequences among major Phyla and Classes of Proteobacteria, Actinobacteria and Planctomycetes, defined as those with a relative abundance $>1 \%$ in at least one sample (Figure 3). OTUs classified as Gammaproteobacteria were by far the most abundant in both size fractions. Alphaproteobacteria, Betaproteobacteria and Deltaproteobacteria were more abundant in the free-living size fraction than in the attached. In the free-living fraction, seven of these major groups had significant differential relative abundance between in situ and $\mathrm{CO}_{2}$-treatments or across $\mathrm{CO}_{2}$-treatments (Figure 3 and Supplementary Table 2). Four of these were bacterial groups: SAR202 in the phylum Chloroflexi $(P=0.017)$, OM190 in the Planctomycetes $(P=0.024)$, SAR406 in the $\mathrm{AB} 16(P=0.022)$ and Verrucomicrobiae in the Verrucomicrobia $(P=0.047)$. Both dominant archaeal groups were also found with differential relative abundances in the free-living fraction: Thaumarchaeota $(P=0.094)$ and Thermoplasmata in the Euryarchaeota $(P=0.026)$. Eukaryotic microbial phytoplankton detected by chloroplast $16 \mathrm{~S}$ reads were also significantly affected by treatments $(P=0.011)$, being less abundant experimental containers compared to in situ. In the attached fraction, only OTUs classified as Flavobacteria in the Bacteroidetes $(P=0.079)$ were found with significant differential relative abundance, with fewer Flavobacteria reads in the containers compared to in situ.

Because Gammaproteobacteria were overall the most abundant class, we increased its taxonomic resolution to determine if the relative abundance of specific clades had been affected by the experimental conditions (Figure 4 and Supplementary Table 3). Alteromonadales constituted by far the most abundant lineage of Gammaproteobacteria in both size fractions, and were differentially abundant across samples in the free-living fraction $(P=$ 0.054); free-living Alteromonadales were most abundant in the control samples, with a mean relative abundance of 0.29 ( $S D \pm$ 0.12 ) compared to an in situ relative abundance of $0.1( \pm 0.04)$. Interestingly, in both the $\mathrm{CO}_{2}$-treatments (mid- and high- $\mathrm{CO}_{2}$ ) values were similar to those in situ suggesting no or little "bottle effect"; free-living Alteromonadales, had similar relative abundances to those found in natural conditions (Supplementary Table 3). In the attached fraction, only Oceanospirillales were found to have significant differential relative abundances across conditions $(P=0.001)$; attached Oceanospirillales were quite abundant in the natural samples $(0.098 \pm 0.03)$, but their relative

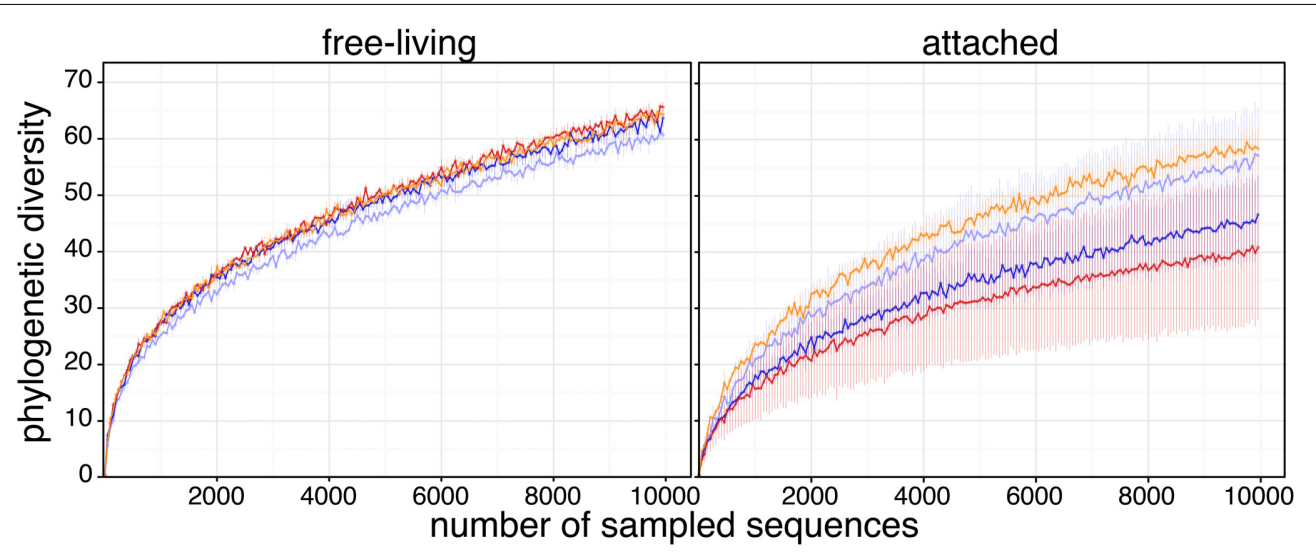

FIGURE 2 | Phylogenetic diversity rarefaction curves. Phylogenetic diversity (mean \pm s.e.m.) was measured as the sum of branch lengths of the $16 S$ OTU phylogenetic tree for each rarefied sequence pool. Sequence datasets were rarefied to 10,000 sequences and were sampled using a step of 50 sequences; rarefaction sampling was reiterated 1000 times. Sample color code is as in Figure 1 


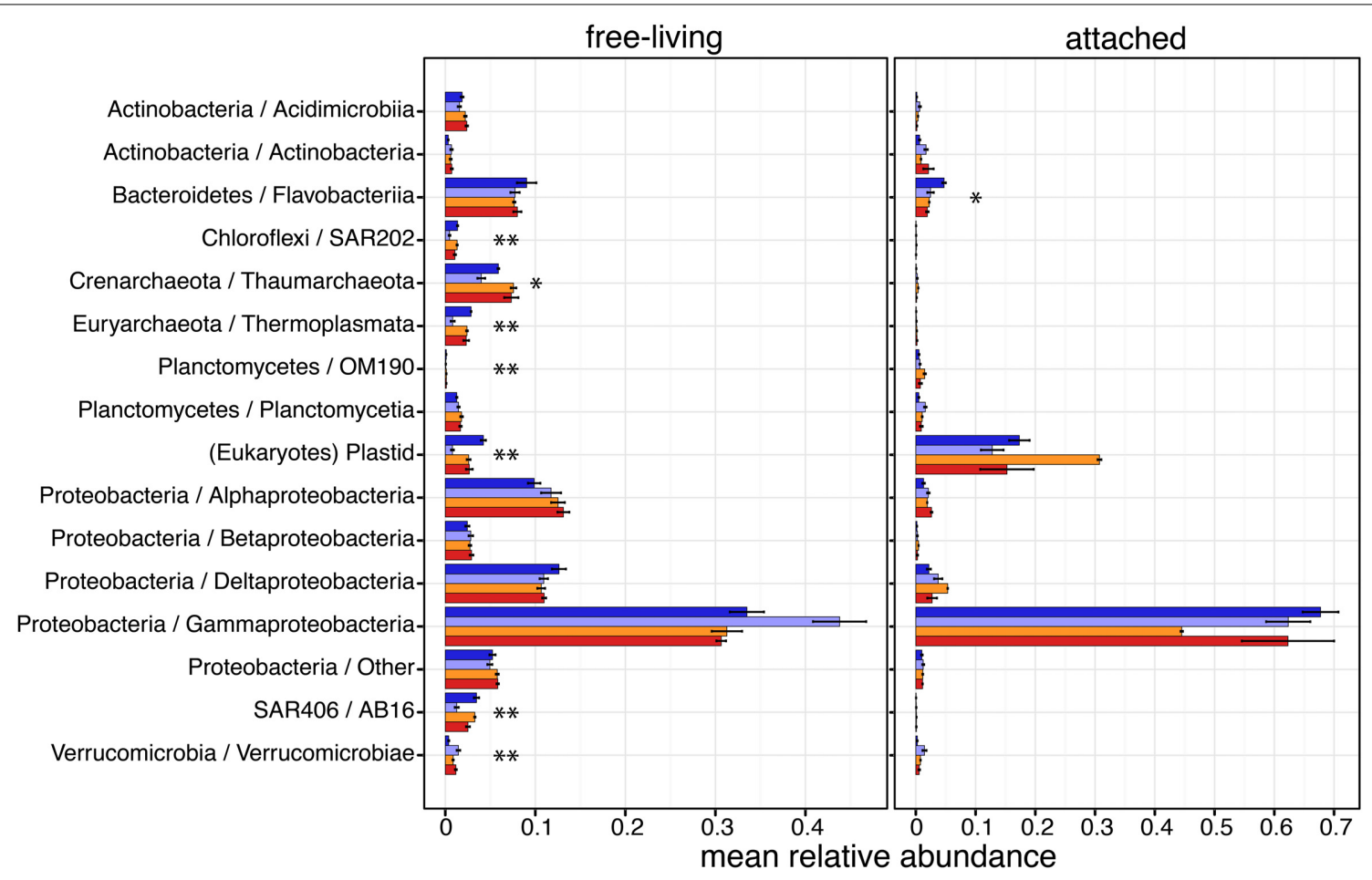

FIGURE 3 | Taxonomic compositions of Arctic pelagic microbial communities based on relative abundances (mean \pm s.e.m.) of $16 \mathrm{~S}$ sequences. Only taxonomic groups with mean relative abundances $>1 \%$ in at least one sample are shown. Sample color code is as in Figure $\mathbf{1 .}$ Asterisks indicate taxonomic groups with significantly different relative abundances between conditions (ANOVA; $* P<0.1$, ** $P<0.05$ ).

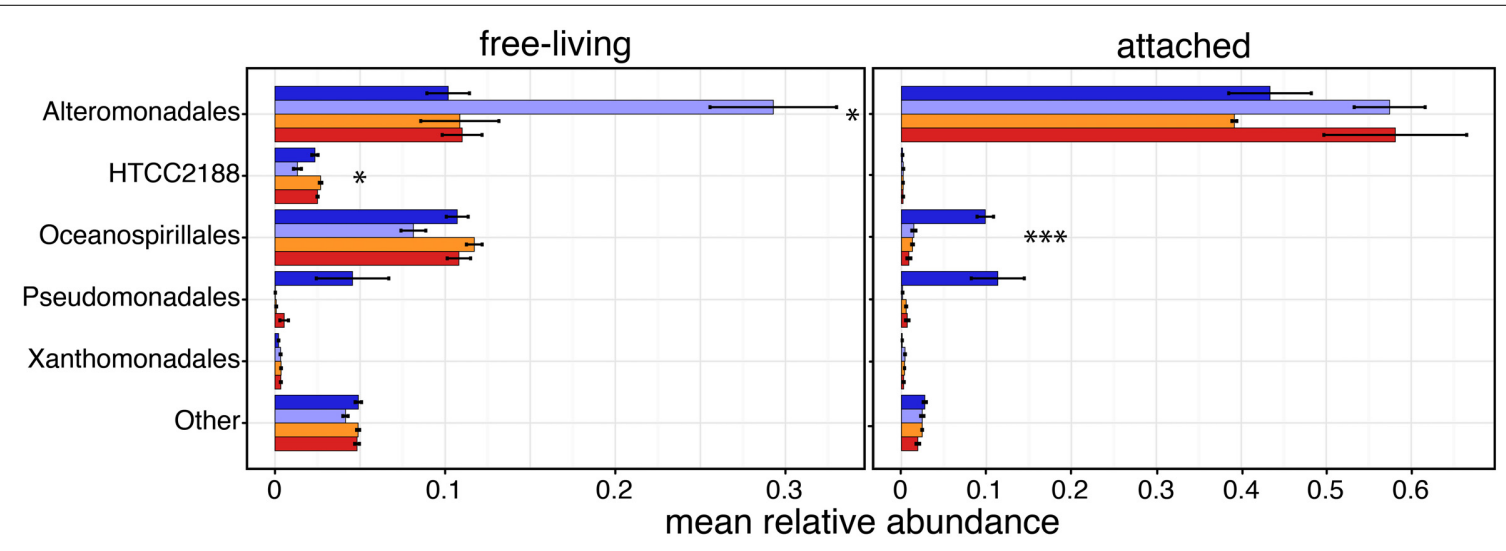

FIGURE 4 | Taxonomic compositions of the most abundant Gammaproteobacteria taxa (mean relative abundances $>0.5 \%$ in at least one sample) based on relative abundances (mean \pm s.e.m.) of $16 \mathrm{~S}$ sequences. Sample color code as in Figure 1. Asterisks indicate taxonomic groups with significantly different relative abundances between conditions (ANOVA; $* P<0.1, * * * P<0.01$ ). abundance was nearly 10 -fold lower in the bottles, especially in the control $(0.014 \pm 0.008)$ and $\mathrm{CO}_{2}$-treated (e.g., mid- $\mathrm{CO}_{2}$ : $0.013 \pm 0.002)$ conditions.

\section{ACIDIFICATION EFFECTS ON COMMUNITY PHYLOGENETIC STRUCTURE}

We next examined the effects of $\mathrm{CO}_{2}$-treatments on the phylogenetic structure of each dominant taxonomic group. To this end, we used the net relatedness index (NRI) as a proxy for phylogenetic clustering (Webb et al., 2002). For a given community, positive NRI reflects phylogenetic clustering, indicating that the community is composed of taxa more evolutionarily related than randomly assembled communities. Such clustering can be an indicator of habitat filtering, where environmental conditions favor taxa with specific ecological traits, implying phylogenetic relatedness among taxa. In contrast, negative NRI reveals phylogenetic overdispersion, which indicates that taxa are less related than expected by chance. This overdispersion can potentially reflect exclusion by competition, 
where a taxon outcompeted closely related organisms exhibiting similar ecological traits.

Overall, we found that the different dominant taxonomic groups were phylogenetically structured, with a large majority of these exhibiting positive NRI values (Figure 5 and Supplementary Table 4). Five dominant taxonomic groups in the free-living fraction and three in the particle-attached had significant differences in their NRI across conditions. However, we found only a few cases of the phylogenetic structure of groups being impacted by $\mathrm{CO}_{2}$-treatment, specifically; Acidimicrobiia and Deltaproteobacteria. Acidimicrobiia was the only clade found to have significantly different NRI values in both size fractions. Free-living Acidimicrobiia communities were overdispersed in natural conditions but became clustered once isolated in bottles for control or $\mathrm{CO}_{2}$-treatements (Supplementary Table 4), with significant differences in NRI $(P=0.097)$. In contrast to their free-living counterparts, attached Acidimicrobiia became more overdispersed under higher $\mathrm{CO}_{2}$ levels $(P=0.005)$. We observed that the NRI of free-living Deltaproteobacteria communities decreased when exposed to higher $\mathrm{CO}_{2}$ levels. Bottled Verrucomicrobia communities from the small size fraction were found to have higher NRI values than in situ counterparts.

\section{MULTIVARIATE ANALYSIS}

The shifts in community structure were investigated further using canonical correspondence analysis (CCA) of the OTUs alongside the carbonate system parameters measured in each treatment.
The ordination distributions confirmed the difference in communities between the free-living (Supplementary Figure 3A) and attached (Supplementary Figure 3B) fractions. In terms of whole communities, the particle-attached bacteria showed higher variability among treatments, especially along axis 1 representing $87.54 \%$ of the variation, which was influenced by alkalinity, $\mathrm{HCO}_{3}$ and DIC. Conversely, the free-living communities of the treatments clustered together in ordination space along axis 1 (67.6\% of the variation), which was largely affected by $p \mathrm{CO}_{2}$, $\mathrm{CO}_{3}^{2-}$ and $\mathrm{pH}$.

The attached Gammaproteobacteria communities were divided mostly according to alkalinity (axis 2; 22\% of the variation) (Supplementary Figure 4A). Although axis 1 explained $77.9 \%$ of the variation, it primarily affected the separation of one outlier replicate of the high- $\mathrm{CO}_{2}$ treatment. The free-living Gammaproteobacteria communities were affected by changes in $p \mathrm{CO}_{2}$, DIC and $\mathrm{HCO}_{3}^{-}$(axis $1 ; 60.4 \%$ of the variation), mostly separating the mid- $\mathrm{CO}_{2}$ and high- $\mathrm{CO}_{2}$ treatments from the controls (Supplementary Figure 4B). The alkalinity also influenced these free-living Gammaproteobacteria communities, compared to the whole community (Axis $2 ; 34.6 \%$ of the variation).

\section{DISCUSSION COMMUNITY DIFFERENCES}

The goal of our study was to assess the major components of the community changed, in terms of phylogenetic and taxonomic structure, in response to short-term $\mathrm{pH}$ modifications. Miller

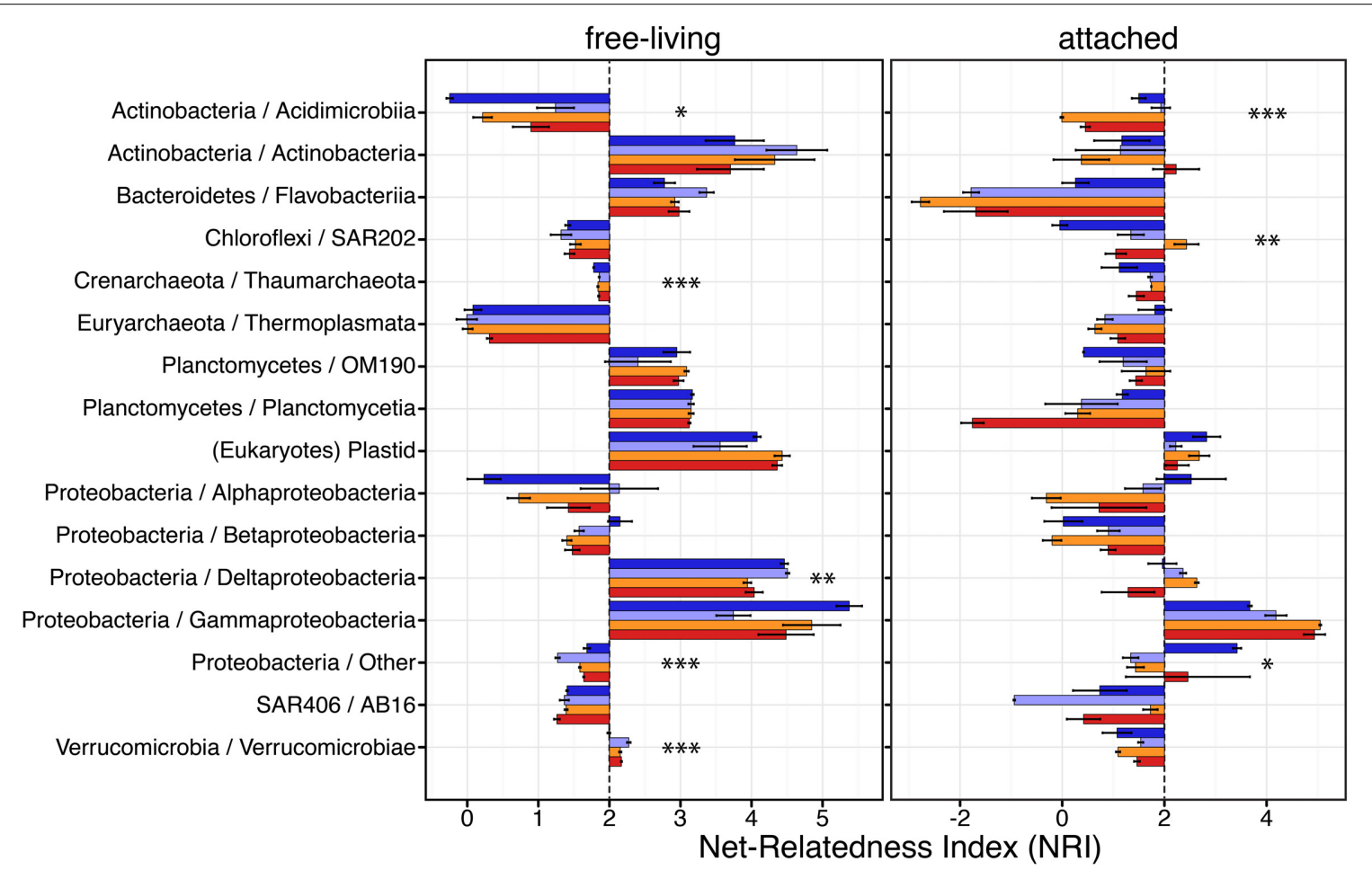

FIGURE 5 | Phylogenetic clustering of the Arctic pelagic microbial communities exposed to different $\mathbf{C O}_{2}$ concentrations. Net-relatedness index (NRI, based on mean pairwise distances) measures branch-tip phylogenetic clustering. Sample color code as in Figure 1. Asterisks indicate taxonomic groups with significantly different NRI between conditions (ANOVA; $* P<0.1, * * P<0.05, * * * P<0.01$ ). 
et al. (2011) reported rapid increases in $p \mathrm{CO}_{2}$ below Arctic ice and for this reason the experiments were carried out over 6 days to assess community response to such short-term increases in $\mathrm{CO}_{2}$. A major goal was to assess whether such increases would change the community structure, for example by selecting taxa more able to cope with more acidic conditions or if the community remained the same, implying more physiological plasticity among the microbes present. It would follow that if communities are plastic then these communities would remain taxonomically stable over the long term, despite anthropogenic increases of $p \mathrm{CO}_{2}$, provided these changes were of the same order. The NRI values provided us with a means of comparing the phylogenetic structure of the natural and $\mathrm{CO}_{2}$-exposed communities. The advantage of this approach is that it is independent from any "taxonomic lexicon," that is, the phylogenetic information is used directly rather than mapping OTUs onto taxonomic information. Using NRI, we could determine and test for the fluctuations in phylogenetic structure across natural, control and $\mathrm{CO}_{2}$-exposed communities, rather than just relying on taxonomic nomenclature.

The major differences detected were between the attached and free-living communities, with significant differences in betadiversity, taxonomy, and phylogenetic structure in free-living compared to the particle-attached communities (Figures 1, 2). Although in the open ocean the differences between attached and free-living communities vary, generally there are differences in coastal regions (Campbell and Kirchman, 2012; Mohit et al., 2014). Most studies in the Arctic are in more coastal waters, and it is clear that the particles represent a distinct environment in these regions (Garneau et al., 2006, 2009), as well as in the more offshore Beaufort Sea open ocean region (Kellogg and Deming, 2009; Ortega-Retuerta et al., 2013). Differences in taxonomic compositions of the particle-attached and freeliving communities are likely dependent on the origin and age of particles, which influences their physical properties and organic content (Pinhassi et al., 1999; Ortega-Retuerta et al., 2013). In terms of alpha-diversity, the Arctic free-living communities were more diverse than the particle-attached assemblages (Figure 2). Interestingly Kellogg and Deming (2009) reported lower diversity for attached than free-living communities in the Laptev Sea, however in Kongsfjord, Svalbard and along the Beaufort Shelf particle attached bacteria were more diverse (Ortega-Retuerta et al., 2013; Sperling et al., 2013). This limited data would be consistent with regions away from direct river or coastal influence having less diverse particle types and as a consequence the attached bacteria are less diverse. Our data could therefore be indicative of the winter-time conditions when there is minimal river and/or coastal influence.

The attached communities in our study were also more overdispersed than the free-living, which would be consistent with patchiness of particles within the environment and an artifact of the low volumes filtered. Each particle can be considered as a distinct habitat, with an initial founder community that is gradually replaced by a succession of bacteria that eventually results in the complete the degradation of the particle (Huston and Deming, 2002; Arnosti, 2008). The effect would force the net relatedness index of their combined communities to be over-dispersed. In contrast, the free-living organisms are affected by the environmental conditions at smaller scales and an incubation volume of $2 \mathrm{~L}$ would include more of the range of possible conditions selecting for a more closely related consortium. In sum, the attached communities may have been under-sampled, causing this lower overall diversity and strong variability. Neither community reached asymptotic and further high-throughput sampling may be required.

In general, for the Arctic marine microbial communities found in our study, the experimental $\mathrm{CO}_{2}$ enrichment had little influence on alpha- or beta-diversity. Other studies of ocean acidification on Arctic marine bacterioplankton communities similarly report that acidification does not appear to be a major factor influencing microbial community assemblages. A mesocosm acidification experiment on Arctic plankton communities carried out in Kongsfjord Svalbard revealed that the compositional change was explained by a concomitant phytoplankton bloom and temperature changes with little or no effect attributed directly to acidification levels (Roy et al., 2013). Sperling et al. (2013) suggested that any effect of acidification was indirectly a response to viral lysis of phytoplankton in the post-bloom phase under higher $\mathrm{CO}_{2}$ leading to the release of particulate organic substrates, which stimulated the bacterial community. Since we did not create a bloom in our experiment, nor monitor viral production, the two experiments are difficult to reconcile, except to state that acidification per se probably has little influence on bacterial communities in the Arctic over the short term. Indeed, although there was wide variability, the results of the CCA analysis suggest that in several cases alkalinity was a stronger driver than $\mathrm{pH}$ or $p \mathrm{CO}_{2}$ conditions (Supplementary Figures 3, 4). Alkalinity shifts could be important for the Arctic, as alkalinity is influenced by freshening and river inputs and flow, and thus requires further investigation.

For the free-living fraction there were more instances of changes between the in situ and control communities compared to the in situ and high $\mathrm{CO}_{2}$ treatments in our study, suggesting that a parameter in the higher $\mathrm{CO}_{2}$ treatments compensated for containerization. In contrast, there was no such pattern in the attached communities. Similarly, Allgaier et al. (2008) reported changes in the community of free-living bacteria but not in the larger size fraction in response to changes in acidification. Roy et al. (2013) also found a greater effect on the Gammaproteobacteria in the free-living fraction than with the particle-attached communities at higher $p \mathrm{CO}_{2}$ levels. A more pronounced response of the smaller free-living cells to the ambient conditions may be a consequence the greater influence of molecular diffusive processes on smaller cells (Yoshiyama and Klausmeier, 2008), whereas bacteria attached to particles are more likely to be surrounded by larger organic molecules (Malfatti and Azam, 2009) offering some protection from rapid chemical changes in the environment. However, the net effect on bacterial production is a separate question, which we did not address as we did not measure production. Interestingly, Grossart et al. (2006), found that in response to high $p \mathrm{CO}_{2}$, particleattached communities were more active, in terms of protein production, than the free-living communities.

In most previous acidification experiments on microbial communities, changes in the bacterial communities were closely 
correlated with system productivity (Grossart et al., 2006; Allgaier et al., 2008; Roy et al., 2013). Additionally, Newbold et al. (2012) showed that acidification has a greater effect on picoeukaryotes than bacteria, supporting the idea that the changing $p \mathrm{CO}_{2}$ conditions have an indirect effect on bacterial communities through the re-structuring of phytoplankton communities. Additionally, acidification could hamper compositional shifts orchestrated by other environmental variables, as indicated by reports that the shift in Arctic bacterial community composition induced by glucose amendments is mitigated under acidified conditions (Ray et al., 2012). Therefore, although increased $p \mathrm{CO}_{2}$ had little direct impacts on the prokaryote taxonomic composition and phylogenetic structure, it could have indirect effects on microbial communities. The Catlin Arctic Survey also investigated the effects of $\mathrm{OA}$ at higher trophic levels and report that Pteropods were only weakly affected by acidification (Comeau et al., 2012) and copepod species showed contrasting responses to acidification, with the small Oithona species reacting more strongly than the larger Calanus (Lewis et al., 2013). The latter conducts deep vertical migrations through the water column under the winter ice whereas Oithona stay in the surface water layer. Hence Calanus and similarly the pteropods, are regularly exposed to varying concentrations of $\mathrm{CO}_{2}$ as they undergo their daily vertical migration, potentially making them less sensitive to changes in $\mathrm{CO}_{2}$ compared to the smaller non-vertically migrating Oithona (Lewis et al., 2013). These contrasting results across the food webs warrant further, collaborative investigations into whole ecosystem responses to $\mathrm{OA}$. In addition, to predict the net effects of OA there is a need to evaluate the indirect responses of microbial communities perhaps by investigating many communities under a range of conditions including naturally high $\mathrm{CO}_{2}$ conditions related to increased photosynthesis or venting.

The minimal responses of bacterial communities to acidification reported here and elsewhere are likely the result of a tolerance of the microbial communities to changes in $\mathrm{pH}$ and $\mathrm{CO}_{2}$ established by the natural variability in ocean conditions (McNeil, 2010; McNeil et al., 2010; Gilbert, 2011). Daily pH variability is caused by tides, upwelling of deep waters and other ocean processes affecting mostly coastal systems and causing fluctuations of $p H>0.25$ (Hofmann et al., 2011). While daily variability is less accentuated in the Antarctic (McNeil, 2010; Matson et al., 2011), there is limited comparable data for the Arctic. However formation and melting of ice can heighten the extent of $\mathrm{pH}$ and $p \mathrm{CO}_{2}$ excursions that microbial communities must contend with on a seasonal scale (Shadwick et al., 2013). The presence of sea ice induces a disequilibrium of $\mathrm{CO}_{2}$ exchanges between the water and the atmosphere, and during its formation expulsion of brines containing higher concentrations of Total Inorganic Carbon (TIC) into the underlying waters will cause an increase in their $p \mathrm{CO}_{2}$ content (Miller et al., 2011).

Moreover, a large part of the seasonal variability in the Arctic Ocean $\mathrm{pH}$ and $p \mathrm{CO}_{2}$ is a consequence of microbial activities; heterotrophic bacterial communities tend to increase $p \mathrm{CO}_{2}$ through respiration within and under the ice (Bates and Mathis, 2009; Nguyen et al., 2012). These biologically induced changes in $\mathrm{pH}$ and $p \mathrm{CO}_{2}$ take place on time scales much shorter than the projected OA due to climate change. The marine microorganisms behind these biogeochemical processes might already be adapted to respond to varying $\mathrm{pH}$ and $p \mathrm{CO}_{2}$ conditions. Indeed, $\mathrm{pH}$ and $p \mathrm{CO}_{2}$ also varies with depth, and hence microbial assemblages can contain similar bacterial lineages along a range of conditions (DeLong et al., 2006). This spatial and temporal variability is consistent with our results in the sense that the experimental $\mathrm{CO}_{2}$ treatments were likely not far outside the range of natural short-term variability experienced by the microbial community as a whole, thus precluding any marked taxonomic changes in the communities.

\section{HIGHER TAXONOMIC RESOLUTION: GAMMAPROTEOBACTERIA}

Gammaproteobacteria were by far the most abundant taxa in both size fractions, consistent with the report of clone libraries of $>3$ and $<3 \mu \mathrm{m}$ fractions dominated by Gammaproteobacteria in the Laptev Sea (Kellogg and Deming, 2009). In contrast, Collins et al. (2010) found Alphaproteobacteria to dominate the microbial communities, mostly from the SAR11 clade during the same season as our study. Alonso-Sáez et al. (2012) found, using fluorescence in situ hybridizations combined with autoradiography, that under the ice Gammaproteobacteria appeared at lower concentrations but had a greater proportion of active cells compared to the numerically dominant SAR11 clade.

In contrast to reports from post-bloom conditions, where Gammaproteobacteria are the only free-living taxon affected by acidification (Roy et al., 2013), the Gammaproteobacteria relative abundance did not vary with containment or $\mathrm{CO}_{2}$-treatment in our experiment. Nonetheless, exploring higher taxonomic resolutions revealed some variability within the Gammaproteobacteria mostly in response to containment. Alternomonadales in the freeliving community increased when contained in the incubation bottles, but was nearer the in situ proportion in the higher $\mathrm{CO}_{2}$ treatments. Alternomonadales are among the most easily isolated marine bacteria from enrichment cultures (Lovejoy personal observation) and the change in $\mathrm{pH}$ may have influenced quorum sensing in the containers. In the particle-attached fraction the Oceanospirillales were significantly less abundant in all experimental bottles compared to the in situ samples, and may have reflected a lack of suitable high molecular weight substrate for this group or the effect of the 50 micron pre-screening if the Oceanospirillales were associated with animals (La Riviere et al., 2013).

In terms of phylogenetic structure, Gammaproteobacteria did not show significant responses to either acidification or bottle containment. This resilience of Gammaproteobacteria to increased $\mathrm{CO}_{2}$ levels could be linked to maintenance of intracellular $\mathrm{pH}$ homeostasis at higher environmental $\mathrm{CO}_{2}$, as reported for several Gammaproteobacteria species (Zhao and Houry, 2010).

The in situ prevalence of free-living archaeal Thaumarcheota, in surface waters of the Arctic has been reported previously (Garneau et al., 2006; Comeau et al., 2011), although they represented $<10 \%$ of the total prokaryote reads, compared to $18 \%$ in ice-covered surface waters of the Beaufort Sea (Alonso-Sáez et al., 2012). The lower relative abundance of Thaumarcheota in our study may have been related to substrate availability (Pedneault et al., 2014). Alternatively, methodological differences and primer bias cannot be discounted. The somewhat significant differences 
in the Thaumarcheota among experimental treatments appear to be more closely linked to containment than to the effects of $\mathrm{CO}_{2}$ (Supplementary Table 2).

\section{BOTTLE AND MULTIPLE DOMAIN EFFECTS}

Overall although we found a number of clusters with high support suggesting similarity of communities, there was no clear association with any particular treatment and we were not able to identify any factors driving community composition. In fact, this suggests that there were a finite number of community outcomes from the starting community and stochastic processes were predominant. Containment facilitates experimental manipulation of growth conditions and is a valuable tool for understanding how living organisms and communities react to specific variables, it can also be used to select for species with traits that enable growth under specific conditions (Zobell, 1943; Ferguson et al., 1984; Massana et al., 2001). However, in nature plankton are subjected to advective flow and diffusion in addition to biological processes and interactions. Since containment ceases the advective flow of cells, nutrients, and metabolites, it can cause bias by what is referred to as the "bottle effect" (Whipple, 1901). Here we compared in situ samples with ambiant- $\mathrm{CO}_{2}$, mid- $\mathrm{CO}_{2}$ and high $\mathrm{CO}_{2}$ conditions, with the aim to control for the effect of experimental confinement on natural bacterial community composition. In fact, the majority of the significant changes in taxonomic abundance and phylogenetic structure, particularly for the attached communities, were in response to containment.

Interestingly more significant changes were observed between the in situ and the control (ambiant- $\mathrm{CO}_{2}$ ) bottles, with fewer differences detected between the in situ and mid- and high- $\mathrm{CO}_{2}$ treatments. Hence, we cannot rule out that higher $\mathrm{CO}_{2}$ may have influenced some unmeasured factors including viral infection or predation, which could increase within bottles, therefore mimicking the effects of a more open "natural" system, where growth and loss rates are balanced.

In contrast to other studies on Arctic waters, we have monitored the effects of acidification on Bacteria and Archaea communities independent of a phytoplankton bloom and suggest that some of the reported effects on bacterial communities were indirect and due to higher primary production and perhaps additional containment effects. While it has been suggested that OA should not have a significant impact on ocean biogeochemical processes, aside from calcification (Joint et al., 2010), the strong bottle effects suggests we are hampered in our ability to genuinely test the effect of acidification on microbial communities. However, despite this we were able to detect small shifts in phylogenetic structure and diversity that could have subtle effects on the maintenance of functionality in a complex community. New in situ tools need to be developed that could monitor such changes.

\section{AUTHOR CONTRIBUTIONS}

All authors wrote the article; Helen S. Findlay designed and conducted field and experimental work; Adam Monier and Connie Lovejoy designed bioinformatics analyses; Adam Monier conducted bioinformatics analyses; Sophie Charvet conducted CCA analysis and provided logistic support:.

\section{ACKNOWLEDGMENTS}

The Catlin Arctic Survey was funded by Catlin Ltd. and coordinated by Geo Mission Ltd. Helen S. Findlay was supported by the PML Lord Kingsland Fellowship and received the Ralph Brown Expedition Grant from the Royal Geographical Society (with IBG) and a Royal Society Travel Grant. The authors are extremely grateful to the Ice Base and Geo Missions staff for their support in carrying out field work, and the other field scientists for assistance in the field. The authors thank J. Gilbert, Argonne National Laboratory, for discussions on experimental design and for sequence analysis. Sample processing, sequencing and core amplicon data analysis were performed by the Earth Microbiome Project (www.earthmicrobiome.org) and all amplicon and metadata have been made public through the data portal (www. microbio.me/emp). Computing support from CLUMEQ and Compute Canada was appreciated. Partial funding for data analyses was from a Natural Science and Engineering Council (NSERC) of Canada and a discovery grant to Connie Lovejoy. Adam Monier is funded through the Canadian Excellence Research Chair (CERC) in remote sensing of Canada's new Arctic frontier. This is a contribution to ArcticNet.

\section{SUPPLEMENTARY MATERIAL}

The Supplementary Material for this article can be found online at: http://www.frontiersin.org/journal/10.3389/fmicb. 2014.00490/abstract

\section{REFERENCES}

Aljanabi, S. M., and Martinez, I. (1997). Universal and rapid salt-extraction of high quality genomic DNA for PCR-based techniques. Nucleic Acids Res. 25, 4692-4693. doi: 10.1093/nar/25.22.4692

Allgaier, M., Riebesell, U., Vogt, M., Thyrhaug, R., and Grossart, H.-P. (2008). Coupling of heterotrophic bacteria to phytoplankton bloom development at different pCO 2 levels: a mesocosm study. Biogeosciences 5, 1007-1022. doi: 10.5194/bg-5-1007-2008

Alonso-Sáez, L., Waller, A. S., Mende, D. R., Bakker, K., Farnelid, H., Yager, P. L., et al. (2012). Role for urea in nitrification by polar marine Archaea. Proc. Natl. Acad. Sci. U.S.A. 109, 17989-17994. doi: 10.1073/pnas.1201914109

Arnosti, C. (2008). Functional differences between Arctic seawater and sedimentary microbial communities: contrasts in microbial hydrolysis of complex substrates. FEMS Microbiol. Ecol. 66, 343-351. doi: 10.1111/j.1574-6941.2008.00587.x

Azam, F., and Malfatti, F. (2007). Microbial structuring of marine ecosystems. Nat. Rev. Microbiol. 5, 782-791. doi: 10.1038/nrmicro1747

Bates, N. R., and Mathis, J. T. (2009). The Arctic Ocean marine carbon cycle: evaluation of air-sea CO 2 exchanges, ocean acidification impacts and potential feedbacks. Biogeosciences 6, 2433-2459. doi: 10.5194/bg-6-2433-2009

Bates, N. R., Mathis, J. T., and Cooper, L. W. (2009). Ocean acidification and biologically induced seasonality of carbonate mineral saturation states in the western Arctic Ocean. J. Geophys. Res. 114, 1978-2012. doi: 10.1029/2008JC004862

Caldeira, K., and Wickett, M. E. (2003). Oceanography: anthropogenic carbon and ocean pH. Nature 425, 365-365. doi: 10.1038/425365a

Campbell, B. J., and Kirchman, D. L. (2012). Bacterial diversity, community structure and potential growth rates along an estuarine salinity gradient. ISME J. 7, 210-220. doi: 10.1038/ismej.2012.93

Caporaso, J. G., Bittinger, K., Bushman, F. D., DeSantis, T. Z., Andersen, G. L., and Knight, R. (2010a). PyNAST: a flexible tool for aligning sequences to a template alignment. Bioinformatics 26, 266-267. doi: 10.1093/bioinformatics/ btp636

Caporaso, J. G., Kuczynski, J., Stombaugh, J., Bittinger, K., Bushman, F. D., Costello, E. K. et al. (2010b). QIIME allows analysis of high-throughput community sequencing data. Nat. Methods 7, 335-336. doi: 10.1038/nmeth.f.303

Cole, J. R., Wang, Q., Cardenas, E., Fish, J., Chai, B., Farris, R. J., et al. (2007). The ribosomal database project (RDP-II): introducing myRDP space 
and quality controlled public data. Nucleic Acids Res. 35, D169-D172. doi: 10.1093/nar/gkl889

Collins, R. E., Rocap, G., and Deming, J. W. (2010). Persistence of bacterial and archaeal communities in sea ice through an Arctic winter. Environ. Microbiol. 12, 1828-1841. doi: 10.1111/j.1462-2920.2010.02179.x

Comeau, A. M., Li, W. K. W., Tremblay, J.-É., Carmack, E. C., and Lovejoy, C. (2011). Arctic ocean microbial community structure before and after the 2007 record sea ice minimum. PLoS ONE 6:e27492. doi: 10.1371/journal.pone. 0027492

Comeau, S., Alliouane, S., and Gattuso, J.-P. (2012). Effects of ocean acidification on overwintering juvenile Arctic pteropods Limacina helicina. Mar. Ecol. Prog. Ser. 456, 279-284. doi: 10.3354/meps09696

DeLong, E. F., Preston, C. M., Mincer, T., Rich, V., Hallam, S. J., Frigaard, N.-U., et al. (2006). Community genomics among stratified microbial assemblages in the ocean's interior. Science 311, 496-503. doi: 10.1126/science. 1120250

Dickson, A. G., Sabine, C. L., and Christian, J. R. (2007). Guide to Best Practices for Ocean $\mathrm{CO}_{2}$ Measurements. Sidney: North Pacific Marine Science Organization.

Doney, S. C., Fabry, V. J., Feely, R. A., and Kleypas, J. A. (2009). Ocean acidification: the other $\mathrm{CO}_{2}$ problem. Marine Sci. 1, 169-192. doi: 10.1146/annurev.marine. 010908.163834

Edgar, R. C. (2010). Search and clustering orders of magnitude faster than BLAST. Bioinformatics 26, 2460-2461. doi: 10.1093/bioinformatics/btq461

Edgar, R. C., Haas, B. J., Clemente, J. C., Quince, C., and Knight, R. (2011). UCHIME improves sensitivity and speed of chimera detection. Bioinformatics 27, 2194-2200. doi: 10.1093/bioinformatics/btr381

Ferguson, R. L., Buckley, E. N., and Palumbo, A. V. (1984). Response of marine bacterioplankton to differential filtration and confinement. Appl. Environ. Microbiol. 47, 49-55.

Galand, P. E., Alonso-Sáez, L., Bertilsson, S., Lovejoy, C., and Casamayor, E. O. (2013). Contrasting activity patterns determined by BrdU incorporation in bacterial ribotypes from the Arctic Ocean in winter. Front. Microbiol. 4:118. doi: 10.3389/fmicb.2013.00118

Galand, P. E., Lovejoy, C., Pouliot, J., Garneau, M.-E., and Vincent, W. F. (2008). Microbial community diversity and heterotrophic production in a coastal Arctic ecosystem: a stamukhi lake and its source waters. Limnol. Oceanogr. 53, 813. doi: 10.4319/lo.2008.53.2.0813

Garneau, M.-E., Roy, S., Lovejoy, C., Gratton, Y., and Vincent, W. F. (2008). Seasonal dynamics of bacterial biomass and production in a coastal arctic ecosystem: Franklin Bay, western Canadian Arctic. J. Geophys. Res. 113, 1978-2012. doi: 10.1029/2007JC004281

Garneau, M.-E., Vincent, W. F., Alonso-Sáez, L., Gratton, Y., and Lovejoy, C. (2006). Prokaryotic community structure and heterotrophic production in a river-influenced coastal arctic ecosystem. Aquat. Microb. Ecol. 42, 27-40. doi: 10.3354/ame042027

Garneau, M.-E., Vincent, W. F., Terrado, R., and Lovejoy, C. (2009). Importance of particle-associated bacterial heterotrophy in a coastal Arctic ecosystem. J. Marine Syst. 75, 185-197. doi: 10.1016/j.jmarsys.2008.09.002

Gilbert, B. (2011). Joint consequences of dispersal and niche overlap on local diversity and resource use. J. Ecol. 100, 287-296. doi: 10.1111/j.13652745.2011.01908.x

Grossart, H.-P., Allgaier, M., Passow, U., and Riebesell, U. (2006). Testing the effect of $\mathrm{CO}_{2}$ concentration on dynamics of marine heterotrophic bacterioplankton. Limnol. Oceanogr. 51, 1-11. doi: 10.4319/lo.2006.51.1.0001

Hammer, Ø., Harper, D., and Ryan, P. D. (2009). PAST-PAlaeontological STatistics, Ver. 1.89.

Harding, T., Jungblut, A. D., Lovejoy, C., and Vincent, W. F. (2011). Microbes in high arctic snow and implications for the cold biosphere. Appl. Environ. Microbiol. 77, 3234-3243. doi: 10.1128/AEM.02611-10

Hofmann, G. E., Smith, J. E., Johnson, K. S., Send, U., Levin, L. A., Micheli, F., et al. (2011). High-frequency dynamics of ocean $\mathrm{pH}$ : a multi-ecosystem comparison. PLoS ONE 6:e28983. doi: 10.1371/journal.pone.0028983

Huston, A. L., and Deming, J. W. (2002). Relationships between microbial extracellular enzymatic activity and suspended and sinking particulate organic matter: seasonal transformations in the North Water. Deep Sea Res. II Top. Stud. Oceanogr. 49, 5211-5225. doi: 10.1016/S0967-0645(02) 00186-8

Joint, I., Doney, S. C., and Karl, D. M. (2010). Will ocean acidification affect marine microbes and quest. ISME J. 5, 1-7. doi: 10.1038/ismej.2010.79
Junge, K., Eicken, H., and Deming, J. W. (2004). Bacterial activity at- 2 to- 20 $\mathrm{C}$ in Arctic wintertime sea ice. Appl. Environ. Microbiol. 70, 550-557. doi: 10.1128/AEM.70.1.550-557.2004

Kellogg, C. T., and Deming, J. W. (2009). Comparison of free-living, suspended particle, and aggregate-associated bacterial and archaeal communities in the Laptev Sea. Aquat. Microb. Ecol. 57, 1-18. doi: 10.3354/ame01317

Kembel, S. W., Cowan, P. D., Helmus, M. R., Cornwell, W. K., Morlon, H., Ackerly, D. D., et al. (2010). Picante: R tools for integrating phylogenies and ecology. Bioinformatics 26, 1463-1464. doi: 10.1093/bioinformatics/btq166

Krembs, C. E., Eicken, H., Junge, K., and Deming, J. W. (2002). High concentrations of exopolymeric substances in Arctic winter sea ice: implications for the polar ocean carbon cycle and cryoprotection of diatoms. Deep Sea Res. I Oceanogr. Res. Pap. 49, 2163-2181. doi: 10.1016/S0967-0637(02)00122-X

La Riviere, M., Roumagnac, M., Garrabou, J., and Bally, M. (2013). Transient shifts in bacterial communities associated with the temperate gorgonian Paramuricea clavata in the Northwestern Mediterranean Sea. PLOS ONE 8:e57385 doi: 10.1371/journal.pone.0057385

Lavigne, H., and Gattuso, J.-P. (2010). Seacarb: Seawater Carbonate Chemistry with R. R Package Version 2.3. 3.

Lewis, C. N., Brown, K. A., Edwards, L. A., Cooper, G., and Findlay, H. S. (2013). Sensitivity to ocean acidification parallels natural $p \mathrm{CO}_{2}$ gradients experienced by Arctic copepods under winter sea ice. Proc. Natl. Acad. Sci. U.S.A. 110, E4960-E4967. doi: 10.1073/pnas.1315162110

Liu, J., Weinbauer, M. G., Maier, C., Dai, M., and Gattuso, J.-P. (2010). Effect of ocean acidification on microbial diversity and on microbe-driven biogeochemistry and ecosystem functioning. Aquat. Microb. Ecol. 61, 291-305. doi: 10.3354/ame01446

Lozupone, C., and Knight, R. (2005). UniFrac: a new phylogenetic method for comparing microbial communities. Appl. Environ. Microbiol. 71, 8228-8235. doi: 10.1128/AEM.71.12.8228-8235.2005

Malfatti, F., and Azam, F. (2009). Atomic force microscopy reveals microscale networks and possible symbioses among pelagic marine bacteria. Aquat. Microb. Ecol. 58, 1-14. doi: 10.3354/ame01355

Massana, R., Pedrós-Alió, C., Casamayor, E. O., and Gasol, J. M. (2001). Changes in marine bacterioplankton phylogenetic composition during incubations designed to measure biogeochemically significant parameters. Limnol. Oceanogr. 46, 1181-1188. doi: 10.4319/lo.2001.46.5.1181

Mathis, J. T., Pickart, R. S., Byrne, R. H., McNeil, C. L., Moore, G., Juranek, L. W., et al. (2012). Storm-induced upwelling of high $p \mathrm{CO}_{2}$ waters onto the continental shelf of the western Arctic Ocean and implications for carbonate mineral saturation states. Geophys. Res. Lett. 39:L07606. doi: 10.1029/2012GL051574

Matson, P. G., Martz, T. R., and Hofmann, G. E. (2011). High-frequency observations of $\mathrm{pH}$ under Antarctic sea ice in the southern Ross Sea. Antarct. Sci. 23, 607-613. doi: 10.1017/S0954102011000551

McNeil, B. I. (2010). Diagnosing coastal ocean $\mathrm{CO}_{2}$ interannual variability from a 40 year hydrographic time series station off the east coast of Australia. Glob. Biogeochem. Cycles 24:GB4034. doi: 10.1029/2010GB003870

McNeil, B. I., Tagliabue, A., and Sweeney, C. (2010). A multi-decadal delay in the onset of corrosive "acidified" waters in the Ross Sea of Antarctica due to strong air-sea $\mathrm{CO}_{2}$ disequilibrium. Geophys. Res. Lett. 37:L19607. doi: 10.1029/2010GL044597

Meyer, F., Paarmann, D., D’Souza, M., Olson, R., Glass, E. M., Kubal, M., et al. (2008). The metagenomics RAST server-a public resource for the automatic phylogenetic and functional analysis of metagenomes. BMC Bioinformatics 9:386. doi: 10.1186/1471-2105-9-386

Miller, L. A., Papakyriakou, T. N., Collins, R. E., Deming, J. W., Ehn, J. K., Macdonald, R. W., et al. (2011). Carbon dynamics in sea ice: a winter flux time series. J. Geophys. Res. 116, 1978-2012. doi: 10.1029/2009JC006058

Mohit, V., Archambault, P., Toupoint, N., and Lovejoy, C. (2014). Phylogenetic differences in attached and free-living bacterial communities in a temperate coastal lagoon during summer, revealed via high-throughput 16S rRNA gene sequencing. Appl. Environ. Microbiol. 80, 2071-2083. doi: 10.1128/AEM.02916-13

Mühling, M., Fuller, N. J., Somerfield, P. J., Post, A. F., Wilson, W. H., Scanlan, D. J., et al. (2006). High resolution genetic diversity studies of marine Synechococcus isolates using rpoC1-based restriction fragment length polymorphism. Aquat. Microb. Ecol. 45, 263-275. doi: 10.3354/ame045263

Newbold, L. K., Oliver, A. E., Booth, T., Tiwari, B., DeSantis, T., Maguire, M., et al. (2012). The response of marine picoplankton to ocean acidification. Environ. Microbiol. 14, 2293-2307. doi: 10.1111/j.1462-2920.2012.02762.x 
Nguyen, D., Maranger, R., Tremblay, J.-É., and Gosselin, M. (2012). Respiration and bacterial carbon dynamics in the Amundsen Gulf, western Canadian Arctic. J. Geophys. Res. 117, 1978-2012. doi: 10.1029/2011JC007343

Ortega-Retuerta, E., Joux, F., Jeffrey, W. H., and Ghiglione, J. F. (2013). Spatial variability of particle-attached and free-living bacterial diversity in surface waters from the Mackenzie River to the Beaufort Sea (Canadian Arctic). Biogeosciences 10, 2747-2759. doi: 10.5194/bg-10-2747-2013

Pedneault, E., Galand, P. E., Potvin, M., Tremblay, J.-É., and Lovejoy, C. (2014). Archaeal amoA and ureC genes and their transcriptional activity in the Arctic Ocean. Sci. Rep. 4:4661. doi: 10.1038/srep04661

Pinhassi, J., Azam, F., Hemphälä, J., Long, R. A., Martinez, J., Zweifel, U. L., et al. (1999). Coupling between bacterioplankton species composition, population dynamics, and organic matter degradation. Aquat. Microb. Ecol. 17:13. doi: 10.3354/ame017013

Price, M. N., Dehal, P. S., and Arkin, A. P. (2010). FastTree 2-approximately maximum-likelihood trees for large alignments. PLoS ONE 5:e9490. doi: 10.1371/journal.pone.0009490

Raven, J., Caldeira, K., Elderfield, H., Hoegh-Guldberg, O., Liss, P., Riebesell, U., et al. (2005). Ocean Acidification Due to Increasing Atmospheric Carbon Dioxide. London: The Royal Society.

Ray, J. L., Töpper, B., An, S., Silyakova, A., Spindelböck, J., Thyrhaug, R., et al. (2012). Effect of increased $p \mathrm{CO}_{2}$ on bacterial assemblage shifts in response to glucose addition in Fram Strait seawater mesocosms. FEMS Microbiol. Ecol. 82, 713-723. doi: 10.1111/j.1574-6941.2012.01443.x

Rich, J., Gosselin, M., Sherr, E., Sherr, B., and Kirchman, D. L. (1997). High bacterial production, uptake and concentrations of dissolved organic matter in the Central Arctic Ocean. Deep Sea Res. II Top. Stud. Oceanogr. 44, 1645-1663. doi: 10.1016/S0967-0645(97)00058-1

Riebesell, U., Fabry, V. J., Hansson, L., and Gattuso, J.-P. (2010). Guide to Best Practices for Ocean Acidification Research and Data Reporting. Luxembourg: Publications Office of the European Union Luxembourg.

Rochelle-Newall, E., Delille, B., Frankignoulle, M., Gattuso, J.-P., Jacquet, S., Riebesell, U., et al. (2004). Chromophoric dissolved organic matter in experimental mesocosms maintained under different $p \mathrm{CO}_{2}$ levels. Mar. Ecol. Prog. Ser. 272, 25-31. doi: 10.3354/meps272025

Roy, A.-S., Gibbons, S. M., Schunck, H., Owens, S., Caporaso, J. G., Sperling, M., et al. (2013). Ocean acidification shows negligible impacts on high-latitude bacterial community structure in coastal pelagic mesocosms. Biogeosciences 10, 555-566. doi: 10.5194/bg-10-555-2013

Sabine, C. L., Feely, R. A., Gruber, N., Key, R. M., Lee, K., Bullister, J. L., et al. (2004). The oceanic sink for anthropogenic $\mathrm{CO}_{2}$. Science 305, 367-371. doi: 10.1126/science. 1097403

Sarmiento, J. L., Gloor, M., Gruber, N., Beaulieu, C., Jacobson, A. R., Mikaloff Fletcher, S. E., et al. (2010). Trends and regional distributions of land and ocean carbon sinks. Biogeosciences 7, 2351-2367. doi: 10.5194/bg-7-2351-2010

Shadwick, E. H., Trull, T. W., Thomas, H., and Gibson, J. (2013). Vulnerability of polar oceans to anthropogenic acidification: comparison of arctic and antarctic seasonal cycles. Sci. Rep. 3:2339. doi: 10.1038/srep02339

Sperling, M., Piontek, J., Gerdts, G., Wichels, A., Schunck, H., Roy, A. S., et al. (2013). Effect of elevated $\mathrm{CO}_{2}$ on the dynamics of particle-attached and free-living bacterioplankton communities in an Arctic fjord. Biogeosciences 10, 181-191. doi: 10.5194/bg-10-181-2013

Steinacher, M., Joos, F., Frölicher, T. L., Plattner, G.-K., and Doney, S. C. (2009). Imminent ocean acidification in the Arctic projected with the NCAR global coupled carbon cycle-climate model. Biogeosciences 6, 515-533. doi: 10.5194/bg6-515-2009

Tanaka, T., Thingstad, T. F., Lovdal, T., Grossart, H.-P., Larsen, A., Allgaier, M., et al. (2008). Availability of phosphate for phytoplankton and bacteria and of labile organic carbon for bacteria at different $p \mathrm{CO}_{2}$ levels in a mesocosm study. Biogeosciences 5, 669-678. doi: 10.5194/bg-5-669-2008

Thurber, R. V., Willner Hall, D., Rodriguez-Mueller, B., Desnues, C., Edwards, R. A., Angly, F., et al. (2009). Metagenomic analysis of stressed coral holobionts. Environ. Microbiol. 11, 2148-2163. doi: 10.1111/j.1462-2920.2009. 01935.x

Wang, Q., Garrity, G. M., Tiedje, J. M., and Cole, J. R. (2007). Naive bayesian classifier for rapid assignment of rRNA sequences into the new bacterial taxonomy. Appl. Environ. Microbiol. 73, 5261-5267. doi: 10.1128/AEM. 00062-07

Webb, C. O., Ackerly, D. D., McPeek, M. A., and Donoghue, M. J. (2002). Phylogenies and community ecology. Annu. Rev. Ecol. Syst. 33, 475-505. doi: 10.1146/annurev.ecolsys.33.010802.150448

Whipple, G. C. (1901). Changes that take place in the bacterial contents of waters during transportation. Tech. Q. MIT 14, 21.

Yoshiyama, K., and Klausmeier, C. A. (2008). Optimal cell size for resource uptake in fluids: a new facet of resource competition. Am. Nat. 171, 59-70. doi: $10.1086 / 523950$

Zhao, B., and Houry, W. A. (2010). Acid stress response in enteropathogenic gammaproteobacteria: an aptitude for survivall. Biochem. Cell Biol. 88, 301-314. doi: 10.1139/O09-182

Zobell, C. E. (1943). The effect of solid surfaces upon bacterial activity. J. Bacteriol. 46, 39. doi: 10.1371/journal.pone.0057385

Conflict of Interest Statement: The authors declare that the research was conducted in the absence of any commercial or financial relationships that could be construed as a potential conflict of interest.

Received: 02 July 2014; accepted: 01 September 2014; published online: 29 September 2014.

Citation: Monier A, Findlay HS, Charvet S and Lovejoy C (2014) Late winter under ice pelagic microbial communities in the high Arctic Ocean and the impact of shortterm exposure to elevated $\mathrm{CO}_{2}$ levels. Front. Microbiol. 5:490. doi: 10.3389/fmicb. 2014.00490

This article was submitted to Extreme Microbiology, a section of the journal Frontiers in Microbiology.

Copyright (c) 2014 Monier, Findlay, Charvet and Lovejoy. This is an open-access article distributed under the terms of the Creative Commons Attribution License (CC BY). The use, distribution or reproduction in other forums is permitted, provided the original author(s) or licensor are credited and that the original publication in this journal is cited, in accordance with accepted academic practice. No use, distribution or reproduction is permitted which does not comply with these terms. 